\title{
TEACHING CAUSATIVE BY USING INDUCTIVE WAY TO THE ELEVENTH GRADE STUDENTS OF SMA MUHAMMADIYAH 9 RAWA BENING OKU TIMUR
}

\author{
Dwi Andriani \\ English Educational Study Program, STKIP Nurul Huda Sukaraja, Indonesia \\ E-mail: dwiandriani@gmail.com
}

\author{
Submit: 24-01-2018 Review: 24-02-2018 Accepted: 24-02-2018 \\ DOI: https://doi.org/10.22202/tus.2018.v4i1.1384
}

\begin{abstract}
The main problem of this study is, "Is it effective to use inductive way in teaching causative to the eleventh grade students of SMA Muhammadiyah 9 Rawa Bening OKU Timur?". The method used in this study was pre-experimental method in one group pretest posttest design. The population was the eleventh grade students of SMA Muhammadiyah 9 Rawa Bening OKU Timur, the total number was 115 students, consisting three classes. The writer took one class as sample by using convenience non random sampling, it was XI.IPA.I, the total number was 40 students. It was found that the average score in pre-test was 6.29 , the average score in post-test was 7.00.The data was analyzed by using matched t-test formula. The result showed the t-obtained was 4.73. on the other hand, the critical value was 1.684 in df (39). Here, $t$ - obtained was higher than t-table. It means that teaching causative by using inductive way to the eleventh grade students of SMA Muhammadiyah 9 Rawa Bening OKU Timur was effective.
\end{abstract}

Key Words: Causative; Inductive Way; Teaching

\section{INTRODUCTION}

The principles of implementing Competency Based Curriculum (CBC) are learner focused, developing learner's creativity, providing challenging and exciting of learning conditions, providing various learning experiences and learning by doing (Juniawan, 2008:86). it also happened for Curriculum 2013. From the sentences, we know that here the students must be active in the class and the teacher is just as a facilitator.

One part of grammar is causative. Causative is used to explain an activity or work which is not done by subject, but because of subject's request ( Han, 2008:89). 
The way of teaching is the skill of teacher to vary the procedures used in presenting the lesson, which is particularly appropriate for the students in order to get a better result of teaching. The success of teaching will depend on the way or method used. The grammar of causative constructions has inspired what is probably one of the most extensive literatures in modern Linguistics.

Many students have difficulty in learning English especially grammar, focused on causative. It happened to SMA Muhammadiyah 9 rawa bening OKU Timur, teacher have the materials with the same way. It made the students' boredom and they just as the receiver and listener. It is clear that our curriculum must focus on students' center. Teachers must be able to choose the methods which connect with it.

There are two ways in teaching grammar: deductive and inductive way (Saleh, 1997:18). In deductive way, the teacher first presents the generalization, rule, or pattern and then gives the learner drills and practice in the use of points of grammar. And on the other hand, inductive way of teaching, the teacher first presents examples have been practiced, the learner is guided in forming the generalization about the rule of the structure.

The writer chooses inductive way for teaching causative in this study because of some reasons: first, this way can stimulate the students' participation in teaching and learning activities. Second, it can provide the students to think critically based on the examples given, so they do not feel bored. Third, the students can discuss and share the ideas or information about the material given.

\section{The Concept of Teaching}

Teaching is showing or helping someone to learn how to do something, giving insctructions, guiding in the study of something, providing with knowledge, causing to know or understand ( Brown, 1980:7).

Teaching is basically an interactive process involving teacher, students and task. ( Gebhard, 2000: 5).

\section{The Concept of Causative}


Sugeng, A, et al (1999:51) states that causative can be used to express idea that "X" causes "Y" to do something. Causative verbs show that somebody / something is indirectly responsible for an action. The subject does not perform the action it self, but causes someone / something else to do it. Causative verbs show that somebody/ something is indirectly responsible for an action. The subject doesn't perform the action itself, but causes someone/ something else to do it.

causative is a two-verb structure that expresses a predicate of causation and a predicate of effect. is important; we must emphasize that in talking about causation we are not referring to some notion of causation in the physical world, but rather to the human conceptualization of causation, which must be based in some fundamental mode or modes of chunking and organizing perceived reality that allows humans to interact successfully with their physical and social environment (Kemmer, \& Verhagen,,1993:117)

\section{The Concept of Inductive Way}

Inductive reasoning is one store a number of specific instances and induces a general law or rule or conclusion which governs or subsumes the specific instances. Inductive process, in which the learner must infer from all the data around him certain rules and meaning (Brown, 1980:86). It means that in inductive way of teching, the learners are not taught grammaticall or other types of rules directly but they are left to discover or induce rules from their experience from their experience of using the language.

In teaching English structure, the teacher provides various example as the data, which are used to process or form the abstraction to find the concept. Then from this concept, the teacher discover a generalization (pattern) of the structure being taught. According to Finochiaro (1989:207): "inductive way is one in which a series of examples or model sentences is given in order to enable the learner to formulate a generalization, description, or rule". It is obvious that in inductive way, the teacher does not explain everything about the material, but he or she helps and elicits the learner to make generalization about the material which is being taught. 
So, it enables the students to communicate in English orally and in written ways as well.

\section{The Procedures of Teaching causative by using inductive way}

The Procedures of Teaching causative by using inductive way was below:

Step 1) Teacher states the general instructional objectives to use causative perfectly.

Step 2) teacher reviews briefly familiar English items needed in the presentation explanation, before presenting of the new item. In this case, teacher reviews subject, verb and object. Teacher stimulates the class by asking the some questions.

Step 3) Teacher says some model sentences two or three times. This step helps the students to learn new teaching point easily.

Step [ 4) teacher asks the class to repeat the sentences in chorus and individually.

Step 5) teacher presents the form and meaning of the structure by demonstration

Step 6) teacher asks questions to enable the class to make generalization,to describe the form, meaning and use of causative verb. He or she elicits students to make the generalization of causative.

Step 7) teacher gives students drills and practice. It is intended to know if the students understand the material.

Step 8) Teacher facilitates the students to say significant points again. A test may be given

Step 9) Teacher asks the class (students) to copy the material into their notebook.

\section{METHODS}

This research used experimental research. That is, pre-experimental design for one group pre test-pot test design. Here, there is pre test before given treatment. So, the result of treatment can be known more accurate, because it compared with pre test. The design was:

$$
\mathrm{O}_{1} \times \mathrm{O}_{2}
$$

Where: 


$$
\begin{array}{ll}
\boldsymbol{O}_{1} & \text { : The Pretest } \\
\mathrm{X} & \text { : treatment by using inductive way } \\
\boldsymbol{O}_{2} & \text { : The Posttest }
\end{array}
$$

\section{Population and Sample of the Research}

For the population of this study, the writer chose the eleventh grade students of SMA Muhammadiyah 9 Rawa Bening Oku Timur. In this case, there were three classes, that was 115 students. For sample, convenience non random sampling was used, where a group of individuals who (conventiently) are available for study, that was XI.IPAI, consisted of 40 students.

\section{Technique for Analyzing Data}

Before the experiment was conducted, pre-test was given to the experimental groups. In constructing the test, there were some steps: (1) preparing the test. The test was in the form of multiple choice test, (2) asking the expert judgement on the apropriateness, it was the writer's advisors (3) trying out the test. The try out was done at SMA Muhammadiyah 2 Karang Tengah because the school had the same acreditation, (4) analyzing the result, whether or not was valid and reliable through KR-21, and (5) producing the final test, (6) conducting the test. In this study, the writer used t-test ( matched t-test) to analyze the data.

\section{FINDING AND DISCUSSION}

In order to find the effectiveness of teaching causative by using inductive way to the eleventh grade students of SMA MUhammadiyah 9 Rawa bening OKU Timur, first, the data were collected using test; pre-test and post-test. The students' average scores in pre test for class XI.IPAI was 6.29 and 7.00 for post-test. The individual score of the student was gotten by using the BSNP calculation (see BSNP, 2006:19), secondly, the calculation of analyzing the data by using matched t-test. The result of matched t-test could be gotten from the table as follows: 
From the calculation by using matched t-test, it was gotten the result of the data that t-obtained was 4.73 and t-table was 1.684 , so t-obtained was more than t-table. It meant that null hyphotesis (Ho) was rejected and consequently alternative hyphotesis (Ha) was accepted.

\section{CONCLUSION}

Based on the findings, the writer conclude that inductive way gives a good effect and contributions to the students' achievement in order to obtained good result of teaching causative to the eleventh grade students of SMA Muhammadiyah 9 Rawa bening OKU Timur. There are some possible things that made inductive way was effective. Inductive way created the students' active in teaching causative to express their mind. Since, inductive way created more active, the students more interested in learning. We got it from the data scores of the students in post-test was higher than in pre-test. In general the calculation of matched t-test was higher than t-critical value.it means that inductive way could improve the studens' English mastery and effective for teaching causative to the eleventh grade students of SMA Muhammadiyah 9 Rawa bening OKU Timur.

Inductive way is a good way to teach grammar, especial causative. So, for all of the teacher of English or the reader, always use inductive way in the process of teaching and learning to make the students to be active in the class for grammar subjecs. 


\section{REFERENCES}

Brown, D. (1980). Principle of language learning and teaching. New Jersey:

Hall-inc, Englewood cliffs.

Finocchiaro, M. (1989). English as a second foreign language. New York: Prentice Hall Regents.

Gebhard, J.G. (2000). Teaching english as a foreign or second language. America: The University of Michigan Press.

Han, L.T. (2000). Glossary of prepositional. Jakarta: Puspa swara.

Juniawan, M.T. (20017). Curriculum and material development. Palembang: PGRI University.

Kemmer,S \& Verhagen,A.(1993). The grammar of causatives and the conceptual structure of events. Sandiego: University of California.

Saleh. Y. (1997). Methodology of TOEFL in Indonesia context book 1. Palembang: Sriwijaya University.

Sugeng, A. et all. (1999). Bahasa inggris untuk SMU kelas 11. Bandung: Grafindo. 